Military Technical College

Kobry Elkobbah, Cairo,

Egypt.

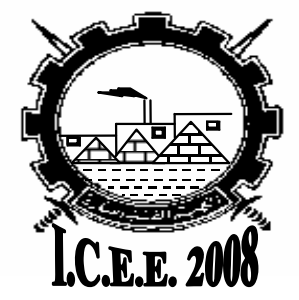

$4^{\text {th }}$ International Conference On

Chemical \& Environmental Engineering

27-29 May 2008

\title{
ABSORPTION OF FLUE GASES IN SEAWATER
}

\author{
RADOJEVIC M.*
}

\begin{abstract}
Existing and proposed technologies for absorbing flue gases into seawater are reviewed. Seawater scrubbing has been employed in industrial plants to desulphurise flue gases by means of conventional absorbers for several decades. More recently, it has been suggested that flue gases may be piped directly to the sea obviating the need for an absorption tower and chimney stack. Almost complete absorption of sulphur dioxide may be achieved by bubbling flue gases into the surface ocean, while effective removal of carbon dioxide requires disposal at considerable depth. Shortcircuiting the environmental cycle by direct disposal of these pollutants into the oceans is an elegant geochemical solutions to many of the problems of air pollution.
\end{abstract}

\section{KEYWORDS}

Air pollution, Desulphurisation, Seawater, Carbon dioxide, Sulphur dioxide 


\section{INTRODUCTION}

Fossil fuel combustion, refining of petroleum, smelting of ores and other industrial processes release huge quantities of pollutants into the atmosphere. Considerable concern has been expressed about two major industrial pollutants, sulphur dioxide $\left(\mathrm{SO}_{2}\right)$ and carbon dioxide $\left(\mathrm{CO}_{2}\right)$ which contribute to acid rain and global warming, respectively. The multifarious consequences of this pollution include: damage to human and animal health, acidification of lakes and rivers and death of fish, damage to forests, and changes in weather and climate. While emissions of these pollutants are expected to decrease in Western Europe and the U.S. over the next 20 years, emissions in developing countries, especially in Asia, are predicted to increase significantly [1].

The abatement of global air pollution problems such as acid rain and global warming is high on the political agendas of national governments and international organisations. Consequently, there is a growing demand for practical and costeffective air pollution control technologies which could be applied to a wide range of industrial plants, especially in developing countries. One important but not widely recognised method, that has been in use for half a century, is absorption of flue gases into seawater [2]. This method has been used to desulphurise flue gases and it is based on the high solubility of $\mathrm{SO}_{2}$ in seawater. Recent research suggests that further improvements, which could extend the efficiency and applicability of this technology, are possible.

Absorption of flue gases into seawater can be effected in one of two ways:

(i) By means of a conventional absorption tower (either spray or packed). This technology is well established and all past and present industrial applications of the seawater scrubbing method are based on it [3].

(ii) By means of direct disposal of flue gases into the sea. This method, which obviates the need for an absorption tower and a chimney stack, has yet to be tried in practice [4].

Control of the two most important flue gases, $\mathrm{SO}_{2}$ and $\mathrm{CO}_{2}$, by means of absorption into seawater will be discussed in the present paper. Theoretical principles, industrial applications, laboratory studies, environmental consequences, and proposed future technologies are reviewed.

\section{INDUSTRIAL PLANTS}

Flue gas desulphurisation (FGD) at industrial plants has been achieved by contacting flue gases with seawater, or other reagents (e.g. lime/limestone), inside conventional absorption towers. One of the earliest applications of FGD was at Battersea power station in London where a desulphurisation plant employing Thames estuarine water with added chalk was built in the 1930s and it achieved $\mathrm{SO}_{2}$ absorption efficiencies of ca. $90 \%$ [5]. In the 1940s the Electrolytic Zinc Company in Tasmania used tidal estuarine water to desulphurise smelter flue gases containing ca. $3 \% \mathrm{SO}_{2}$ with an efficiency of $99.9 \%$ [6]. In the 1960s, seawater was employed to desulphurise boiler flue gases at the Showa Denko Company in Yokohama, Japan [7]. In the 1970s, 
three different FGD systems based on seawater scrubbing were patented in Japan $[8,9,10]$. One of these, involving electrolysed seawater, removed $\mathrm{SO}_{2}$ with an efficiency of $99.9 \%$ [10]. Another involved spraying the flue gas with seawater containing $\mathrm{CaCO}_{3}$, with or without $\mathrm{CaSO}_{4}$, to obtain gypsum [9].

Flue gas desulphurisation efficiencies greater than $99 \%$ have been reported for many of the seawater based scrubbers demonstrating the effectiveness of the process [3]. Some of these claims may be somewhat exaggerated as they are based on a limited number of tests under ideal conditions. Nevertheless, high efficiencies of around 90$95 \%$ may be routinely obtained in practice. The efficiency depends on the liquid/gas $(L / G)$ ratio and higher efficiencies may be easily achieved by increasing this ratio, albeit at a higher cost.

Today, the largest supplier of seawater based FGD absorbers is Alstom who market the seawater FGD system previously known as the Fläkt-Hydro process involving counter-current absorption of flue gases into seawater. This process has been applied at many coastal and island industrial sites across the world, including oil and coal fired boilers, smelters, refineries and incinerators. Fläkt-Hydro seawater based scrubbers operate in Scandinavia, India, Indonesia, Canary Islands, Malaysia and the U.S. (island of Guam) and numerous seawater FGD plants are currently being built or in the planning stage in China. A process involving seawater with lime additive has been developed by Bechtel $[11,12]$.

A flow diagram of a typical seawater scrubbing plant is shown in Fig. 1. Seawater is passed through a screen in order to remove fish, weeds and other suspended materials before being pumped to the top of the scrubbing tower. The seawater is sprayed inside the tower where it reacts with the counter-flowing flue gas. The flue gas is introduced at the bottom of the tower after passing through a dust collection device (e.g. cyclone) in order to remove harmful particulate matter which may be collected by the scrubbing solution and discharged to the sea. After passing through the scrubbing tower the purified gas flows through a reheater before being discharged to the atmosphere via the chimney stack. The reheating of the gas increases plume buoyancy and assists dispersion. The gas can also be passed through a demister to remove any entrained droplets. The spent seawater flows from the bottom of the tower into a water treatment plant. Water treatment may involve dilution with further seawater from the condensers, aeration and/or liming. In addition to expelling absorbed $\mathrm{CO}_{2}$ (if this is deemed desirable) to raise the $\mathrm{pH}$ and assist $\mathrm{SO}_{2}$ oxidation, aeration also raises the $\mathrm{O}_{2}$ content of the effluent to levels suitable for disposal to the sea. The effluent seawater may be diluted with seawater from power station condensers before discharge. In some seawater based desulphurisation plants no water treatment is employed. Either spray or packed absorbers can be used, and it is also possible to operate these either on a once-through basis or with seawater recirculation. 


\section{GASILIQUID EQUILIBRIUM}

In the absorption tower, gaseous pollutants are transferred from a bulk gaseous phase into seawater droplets or films. Sulphur dioxide absorption involves Henry's Law equilibrium followed by rapid dissociation to bisulphite and sulphite ions:

$$
\begin{aligned}
& \mathrm{SO}_{2}+\mathrm{H}_{2} \mathrm{O} \rightleftharpoons \mathrm{HO}_{2} \mathrm{H}_{2} \mathrm{O} \\
& \mathrm{SO}_{2} \cdot \mathrm{H}_{2} \mathrm{O} \stackrel{\mathrm{K}_{1}}{\rightleftharpoons} \mathrm{HSO}_{3}^{-}+\mathrm{H}^{+} \\
& \mathrm{HSO}_{3} \stackrel{\mathrm{K}_{2}}{\rightleftharpoons} \mathrm{SO}_{3}^{2-}+\mathrm{H}^{+}
\end{aligned}
$$

where $\mathrm{H}$ is Henry's Law constant, and $\mathrm{K}_{1}$ and $\mathrm{K}_{2}$ are the first and second dissociation constants respectively, and these are defined in terms of the activities of the various species. The total concentration of dissolved S(IV) may be related to the gaseous partial pressure of $\mathrm{SO}_{2}$ using a pseudo-Henry's Law constant defined as:

$$
H^{*}=H\left\{1+K_{1} / a_{H_{+}}+K_{1} \cdot K_{2} /\left(a_{H_{+}}\right)^{2}\right\}
$$

where $\mathrm{aH}_{\mathrm{H}}$ is the activity of the hydrogen ion. Same equilibria apply to $\mathrm{CO}_{2}$ dissolution except that physically dissolved $\mathrm{CO}_{2}\left(\mathrm{CO}_{2} \mathrm{H}_{2} \mathrm{O}\right)$, bicarbonate $\left(\mathrm{HCO}_{3}{ }^{-}\right)$and carbonate $\left(\mathrm{CO}_{3}{ }^{2-}\right)$ replace physically dissolved $\mathrm{SO}_{2}$, bisulphite and sulphite respectively in equations 1-3. Equilibrium constants for $\mathrm{SO}_{2}$ and $\mathrm{CO}_{2}$ are summarised in Table 1.

The efficiency of absorption, assuming complete equilibration, may be calculated from $[13,14]$ :

$$
E(\%)=\frac{(L / G) \cdot R \cdot T}{(L / G) \cdot R \cdot T+1 / H^{*}} \cdot 100
$$

where $L / G$ is the volumetric liquid to gas ratio, $R$ is the gas constant $(0.082 \mathrm{~L}$ atm $\mathrm{mol}^{-1} \mathrm{~K}^{-1}$ ) and $T$ is the absolute temperature.

Dissolved $\mathrm{SO}_{2}$ is rapidly oxidised to sulphate in seawater: 


$$
\mathrm{SO}_{3}{ }^{2-}+1 / 2 \mathrm{O}_{2} \stackrel{\mathrm{Cl}^{-}}{\longrightarrow} \mathrm{SO}_{4}{ }^{2-}
$$

The reaction involves oxidation by $\mathrm{O}_{2}$ which is significantly enhanced by the high level of chloride present in seawater $[15,16]$. Both the solubility of $\mathrm{SO}_{2}$ and the rate of oxidation increase with increasing $\mathrm{pH}$. On the other hand, $\mathrm{CO}_{2}$ dissolved in seawater is present predominantly in the form of bicarbonate ion, and absorbed $\mathrm{CO}_{2}$ may be desorbed if the solution becomes acidic.

The absorption efficiency is illustrated as a function of the $L / G$ ratio and $\mathrm{pH}$ in Fig. 2 . Almost complete absorption of $\mathrm{SO}_{2}$ can be achieved at relatively low $L / G$ ratios over much of the $\mathrm{pH}$ range. The efficiency of $\mathrm{SO}_{2}$ absorption only begins to drop off significantly at $\mathrm{pHs}<4$. On the other hand, the absorption efficiency of $\mathrm{CO}_{2}$ decreases sharply between $\mathrm{pH}$ of 8 and 5 , remaining constant at $\mathrm{pH}<5$. Much higher $L / G$ ratios are needed to obtain modest absorption efficiencies of $\mathrm{CO}_{2}$. Higher absorption efficiencies of gases could also be achieved by adding alkaline substances such as caustic soda $(\mathrm{NaOH})$ to the seawater scrubbing solution to raise the $\mathrm{pH}$.

Absorption and oxidation of $\mathrm{SO}_{2}$ in seawater will lower the $\mathrm{pH}$ and limit the further uptake of $\mathrm{SO}_{2}$, the solubility of which decreases with increasing acidity. The decrease in $\mathrm{pH}$ is, however, much less pronounced in seawater than in pure water due to the buffering capacity of seawater. The $\mathrm{pH}$ of the liquid effluent from a seawater scrubbing plant depends on the $L / G$ ratio and the concentration of $\mathrm{SO}_{2}$ in the flue gas. Higher $L / G$ ratios would result in high $\mathrm{pH}$ and the effluent could be discharged to the sea without further treatment. Low $L / G$ ratios would result in an acidic effluent which may require dilution with cooling water from condensers or addition of lime prior to discharge.

Theoretical calculations predict extremely high desulphurisation efficiencies (>99\%) at $L / G$ ratios typical of operating scrubbers, in agreement with measurements in actual industrial applications. Although some absorption of $\mathrm{CO}_{2}$ is predicted by calculations, and is observed in practice [17], the process is reversible, in contrast to $\mathrm{SO}_{2}$ absorption which rapidly leads to the formation of stable sulphate ions $[15,16,18]$. Any absorbed $\mathrm{CO}_{2}$ may be desorbed if the solution becomes acidic. The solubility of $\mathrm{CO}_{2}$ is much lower than that of $\mathrm{SO}_{2}$, and at corresponding $L / G$ ratios the absorption efficiency for $\mathrm{CO}_{2}$ is considerably lower than for $\mathrm{SO}_{2}$.

Other flue gases may also be controlled by absorption into seawater. Hydrogen chloride gas, with a Henry's law constant of $20 \mathrm{~mol} \mathrm{~L}^{-1} \mathrm{~atm}^{-1}$, is extremely soluble in water and it will readily dissociate to chloride ions. The Henry's law constant for $\mathrm{H}_{2} \mathrm{~S}$ is $0.1 \mathrm{~mol} \mathrm{~L}^{-1} \mathrm{~atm}^{-1}$, intermediate between that of $\mathrm{CO}_{2}$ and $\mathrm{SO}_{2}$, and it too may be absorbed in seawater. On the other hand, oxides of nitrogen are relatively insoluble and seawater scrubbing cannot be used to reduce $\mathrm{NO}$ or $\mathrm{NO}_{2}$ to any significant extent, as confirmed by laboratory experiments [17]. However, the seawater method may be combined with a method of $\mathrm{NO}_{x}$ removal from flue gases such as selective 
catalytic reduction (SCR) or selective non-catalytic reduction (SNCR) to achieve combined reduction of $\mathrm{SO}_{2}$ and $\mathrm{NO}_{x}$ [19].

\section{LABORATORY STUDIES}

There have been very few laboratory studies of $\mathrm{SO}_{2}$ - seawater interactions and these are summarised in Table 2. Only two of these studies are relevant to the conditions encountered in flue gases; one employed a bench-top scrubber while the other employed a bubbler. These experimental studies confirm theoretical predictions and plant measurements. Studies involving bubblers report $100 \%$ absorption of $\mathrm{SO}_{2}$ [18], some absoption of $\mathrm{CO}_{2}$, and very low absorption of $\mathrm{NO}$ [17].

The buffering capacity of seawater has also been investigated in laboratory experiments $[17,18]$. These studies show that seawater can accommodate significant quantities of acid without a significant change in $\mathrm{pH}$. The buffering capacity begins to break down at around $10^{-3} \mathrm{~mol} \mathrm{I}^{-1} \mathrm{H}^{+}$and at $10^{-2} \mathrm{~mol} \mathrm{I} \mathrm{I}^{-1} \mathrm{H}^{+}$any advantage of using seawater over pure water is lost (Fig. 3).

\section{DIRECT DISPOSAL TO THE SEA}

\section{Surface Ocean}

Theoretical, laboratory and plant studies all show that the efficiency of desulphurisation is a function of the $L / G$ ratio. The contact times in conventional scrubbers are brief, of the order of seconds. This is too short for complete equilibration but, nevertheless, very high desulphurisation efficiencies can be achieved with conventional scrubbers for most applications. For very large power plants it may be difficult to achieve the high $L / G$ ratios using conventional scrubbers. Laboratory studies have shown that $100 \%$ absorption of $\mathrm{SO}_{2}$ may be achieved simply by bubbling the gas into seawater $[17,18]$. Much higher $L / G$ ratios and longer contact times could be achieved if the flue gases could be piped to the sea and bubbled under the surface. Whereas in conventional absorption towers mass transfer is from a bulk gaseous phase into droplets or films of seawater, in this novel method mass transfer is from bubbles of gas into bulk seawater liquid phase. This method obviates the need for an absorption tower and chimney stack [4].

An illustration of a hypothetical direct discharge system is shown in Fig. 4. Flue gas is first passed through a dust collection device (e.g. electrostatic precipitator). A compressor is required to overcome the pressure of water; for each 10 meters of depth one atmosphere of pressure must be overcome. Hydrogen chloride, sulphur dioxide and carbon dioxide in the flue gas will dissolve to give soluble chloride, sulphate and bicarbonate ions. While the method would give quantitative absorption of $\mathrm{HCl}$ and $\mathrm{SO}_{2}$, the absorption efficiency of $\mathrm{CO}_{2}$ in the surface ocean would be considerably lower, and volatilisation of $\mathrm{CO}_{2}$ may occur. It may also be possible to mix air in with the flue gas in order to maintain high dissolved oxygen levels and increase the rate of oxidation of $\mathrm{SO}_{2}$ to sulphate. Also, the flue gases may be passed 
through a $\mathrm{NO}_{x}$ reduction unit (e.g. SCR or SNCR) [19] in order to reduce oxides of nitrogen, before being bubbled underwater. It may be necessary to cool the flue gas prior to discharge since high temperatures can have negative impacts on marine ecosystems. Decreasing the flue gas temperature will also increase the absorption efficiency as the solubility of gases increases with decreasing temperature.

\section{Deep Sea Injection}

Because of the low solubility of $\mathrm{CO}_{2}$ in the surface ocean, disposal and storage of $\mathrm{CO}_{2}$ in the deep ocean has been proposed by a number of workers as a possible solution. Although a number of different schemes have been proposed in the literature these are all hypothetical and have not been tested or tried in practice. Some are just speculative proposals not backed up with hard data while others are based on models of varying degrees of complexity. Table 3 summarises the various proposals for oceanic disposal of $\mathrm{CO}_{2}$. As there are still some uncertainties in our knowledge of the fate of $\mathrm{CO}_{2}$ in the oceans [20,21] these proposals remain to be substantiated.

The proposed methods may be broadly classified into three categories:

(i) Direct bubbling of flue gas at great depth (e.g. $240 \mathrm{~m}$ ).

(ii) Absorption of $\mathrm{CO}_{2}$ into seawater followed by pumping of the effluent from the scrubbing plant into the ocean. Due to the higher density of the $\mathrm{CO}_{2-}^{-}$ containing seawater from the plant than the surrounding seawater, the $\mathrm{CO}_{2}$-containing seawater would sink to the bottom of the ocean.

(iii) Absorption of $\mathrm{CO}_{2}$ into a scrubbing solution (e.g. monoethanolamine) in an absorber followed by recovery of the $\mathrm{CO}_{2}$ and its injection into the sea.

Most of the proposed methods involve recovery of $\mathrm{CO}_{2}$ from the flue gas followed by injection into the sea. Carbon dioxide from the flue gas is first absorbed into a solution inside an absorption tower. Chemical absorbers which have been considered include aqueous solutions of alkalis $(\mathrm{KOH}, \mathrm{NaOH})$, salts $\left(\mathrm{K}_{2} \mathrm{CO}_{3}, \mathrm{Na}_{2} \mathrm{CO}_{3}\right.$, $\mathrm{K}_{3} \mathrm{PO}_{4}$ ) and amines (mono-, di-, and tri-ethanolamine). In the case of monoethanolamine solution the following reaction can be used to illustrate the absorption process:

$$
\mathrm{C}_{2} \mathrm{H}_{4} \mathrm{OHNH}_{2}+\mathrm{H}_{2} \mathrm{O}+\mathrm{CO}_{2} \rightleftharpoons \mathrm{C}_{2} \mathrm{H}_{4} \mathrm{OHNH}_{3}^{+}+\mathrm{HCO}_{3}^{-}
$$

The forward reaction is favoured at lower temperatures whereas high temperatures favour the reverse reaction. Thereafter, the absorbed $\mathrm{CO}_{2}$ is released inside a stripper at high temperature $\left(100-120^{\circ} \mathrm{C}\right)$ and the absorbing solution is recycled back to the absorption tower. Other methods for the recovery of $\mathrm{CO}_{2}$ from the flue gas that have been suggested include cryogenic fractionation and membrane separation [22]. It is proposed that the recovered $\mathrm{CO}_{2}$ be compressed and transported by pipeline to the sea. Varying depths of injection have been proposed. In one proposal it is suggested that the $\mathrm{CO}_{2}$ can be injected into sinking thermohaline currents at a depth 
of $160 \mathrm{~m}$. These currents then carry the $\mathrm{CO}_{2}$ to the bottom of the oceans where, it is claimed, it may remain for up to 500 years $[23,24]$. In other proposals it is suggested that $\mathrm{CO}_{2}$ should be injected at greater depths of up to $3000 \mathrm{~m}$ [25]. The recovered $\mathrm{CO}_{2}$ could be injected into the deep ocean as gas, liquid or solid (dry ice).

A method involving the absorption of $\mathrm{CO}_{2}$ in seawater in a pressurised pipeline followed by injection of this seawater into the ocean at depths of 200 to $400 \mathrm{~m}$ has been patented by Mitsubishi [26]. Since the seawater containing dissolved $\mathrm{CO}_{2}$ has a higher density than ordinary seawater it is expected to sink to the bottom of the ocean where it will accumulate as carbon dioxide hydrate. A similar method has been proposed by Haugan and Drange [27].

Some of these methods have been assessed in terms of their potential cost, and these tend to be prohibitive. It is unlikely that deep sea injection will be practiced in the near future as between 30 and $45 \%$ of the power produced by the power station would be used for operating the $\mathrm{CO}_{2}$ disposal method. One proposed method would even require more energy than could be produced by the power station [28]. Another rather eccentric proposal even suggests the building of floating power stations [25].

The main controversy and point of dispute with these proposed methods seems to be the fate of the disposed $\mathrm{CO}_{2}$ in the oceans. In one study, it was suggested that $\mathrm{CO}_{2}$ so disposed would remain permanently at the bottom of the oceans due to the density of liquid or solid $\mathrm{CO}_{2}$ being greater than that of the overlying seawater [25]. De Baar and Stoll [20] have critically assessed the various proposals for the deep sea disposal of $\mathrm{CO}_{2}$ and concluded that the fix is not permanent; the $\mathrm{CO}_{2}$ would slowly diffuse into the surface ocean and eventually into the atmosphere. They conclude that deep ocean disposal would lead to a delay of several hundred years; for most proposed methods half of the injected $\mathrm{CO}_{2}$ would be released to the atmosphere within 50 to 500 years.

\section{ENVIRONMENTAL IMPACTS}

Seawater is a suitable recipient for pollutants such as $\mathrm{SO}_{2}, \mathrm{CO}_{2}$ and $\mathrm{HCl}$ which are produced mainly by the combustion of fossil fuels. These gases are converted to sulphate, bicarbonate and chloride ions in seawater and these very ions are major constituents of seawater (Table 4). Seawater is a concentrated electrolyte solution containing $18.97 \mathrm{~g} \mathrm{Cl}^{-}, 2.56 \mathrm{~g} \mathrm{SO}_{4}{ }^{2-}$ and $0.14 \mathrm{~g} \mathrm{HCO}_{3}^{-}$per $\mathrm{kg}$. Furthermore, seawater has a considerable buffering capacity and can resist changes in its $\mathrm{pH}$ upon addition of acids. Addition of these ions from flue gases is unlikely to have adverse effects on marine ecosystems which are already adapted to this chemical environment. Minor components in the flue gas such as heavy metals should not pose a problem since these can be minimised by passing the flue gas through a dust control device prior to discharge to the sea. Detailed long-term studies near the outfall from a seawater based desulphurisation plant have not revealed any damage on the local marine ecosystem [29]. Although absorption of flue gases into seawater essentially converts air pollution into water pollution, the effluent from a seawater based desulphurisation 
plant can meet even the most stringent environmental standards such as those in Scandinavia and the European Union as shown by successful operation of plants in Scandinavia and the Canary Islands.

As mentioned previously, seawater exhibits a buffering capacity and can withstand changes to its $\mathrm{pH}$ upon addition of acidic or alkaline substances, unlike fresh waters which suffer markedly upon addition of small quantities of acidic substances in the form of acid rain. The buffering action of seawater is due to the high bicarbonate concentration. Absorption of acidic substances may displace some $\mathrm{CO}_{2}$ out of solution in order to maintain the $\mathrm{pH}$ :

$$
\mathrm{HCO}_{3}^{-}+\mathrm{H}^{+} \rightleftharpoons \mathrm{H}_{2} \mathrm{O}+\mathrm{CO}_{2}
$$

Hence, while controlling one problem, acid rain, the process may be contributing to another, global warming. However, the picture is not so simple as other processes such as those involving borate, calcite and clay minerals can also act to buffer the acidity. In the long term, the seawater $\mathrm{pH}$ is controlled by the so-called "pH-stat" mechanism in which $\mathrm{H}^{+}$ions in solution exchange with $\mathrm{Na}^{+}$ions in clay sediments [30].

A simple calculation demonstrates that if for the next 100 years all the industrial emissions are absorbed into seawater, the background concentration of sulphate in seawater would increase by less than $10^{-3} \%$, a negligible quantity. Assuming a present day seawater $\mathrm{pH}$ of 8 , the $\mathrm{pH}$ of seawater after 100 years would remain virtually unchanged. This negligible effect is due to the buffering capacity of seawater. If seawater had no buffering capacity the resulting $\mathrm{pH}$ would be 6.5 . This calculation assumes a mixing time of 100 years for the oceans, which may be unrealistic due to the slow mixing between the surface and deep ocean. It is estimated that water in the oceans is turned over completely in several hundred years [31]. Nevertheless, this calculation illustrates the ability of the oceans to take up $\mathrm{SO}_{2}$ pollution.

With regard to the deep sea injection of $\mathrm{CO}_{2}$, the environmental consequences are unknown as the method has not been tested in practice. One theoretical assessment suggests unfavourable consequences on marine ecosystems [20].

\section{CONCLUSIONS AND RECOMMENDATIONS}

Seawater scrubbing has been employed successfully for several decades to control industrial emissions of $\mathrm{SO}_{2}$ without any harmful effects on marine ecosystems. Unlike many other processes of FGD (e.g. lime/limestone method), seawater scrubbing creates no solid waste products. Seawater scrubbing is a reliable and simple method with low capital and operating costs, however, its use is restricted to coastal locations. Despite these successes, seawater scrubbing still commands a minor share of the FGD market; one possible reason may be that this little known method has been poorly publicised. Very few reviews of FGD technology mention the 
seawater method. Desulphurisation technology is dominated by lime and limestone methods which control ca. $90 \%$ of the world market in FGD technology. The advantages of seawater scrubbing are apparent from Table 5 in which the seawater method is compared with the currently popular lime/limestone method. Lime/limestone methods rarely achieve efficiencies greater than $90 \%$ and problems due to plugging of scrubbers by limestone slurries are not uncommon, although there have been some recent improvements in this technology. These methods involve the quarrying and transporting of limestone to the plants, preparing the slurry, and disposing of spent slurry. Although all of these steps entail economic costs, the highest cost of the lime/limestone method is environmental; limestone quarries are not only eyesores, but are also a growing threat to our shrinking green belts. On the other hand, seawater scrubbing is a simple, efficient, and inexpensive FGD method with no significant impacts on the environment. Seawater scrubbers could meet the growing demand for practical and cost-effective air pollution control technologies, especially in developing countries. Island nations, and those with access to the sea could find this technology most suitable, as shown by applications in the Canary Islands and Indonesia.

Sulphur dioxide is effectively absorbed into seawater in conventional scrubbers, although direct disposal to the sea would further simplify the process and improve the absorption efficiency. The oceans are the final recipient of water soluble air pollutants even when these are discharged into the atmosphere. These pollutants are eventually transported to the oceans through the hydrological cycle damaging weakly buffered lakes, rivers and soils on the way as well as impacting on materials. Discharging these gases into the oceans represents an elegant geochemical solution to the problems of air pollution, preventing pollutants from entering the atmosphere in the first place. Bubbling flue gases directly into the sea represents a novel and highly effective approach to air pollution control but it still remains to be tested in practice. It appears that effective removal of $\mathrm{CO}_{2}$ may require deep sea disposal. Although several methods for the injection of $\mathrm{CO}_{2}$ into the oceans have been proposed, none has yet been tried. It is unlikely that deep sea injection will be practiced in the near future as a large fraction of the power produced by the power station would go into operating the $\mathrm{CO}_{2}$ disposal method.

Methods involving the disposal of flue gases into the ocean are examples of "biogeochemical engineering" in which natural biogeochemical processes are utilised to solve environmental problems. This represents a novel approach to environmental management.

Future studies should concentrate on field trials of the direct injection of flue gases into the sea as well as finding new applications for the method. Field trials have not yet been carried out and pilot plant studies are urgently required in order to optimise operating parameters (depth of discharge, diffuser type, etc.) and resolve some of the uncertainties regarding the fate of dissolved gases in the ocean. Demonstration of this novel method in practice would greatly benefit the power generation industry since it would demonstrate that fossil fuels can be burnt in an environmentally acceptable manner. 
Furthermore, this technology could be applied to shipping. As emissions from stationary and vehicular sources of $\mathrm{SO}_{2}$ and $\mathrm{NO}_{x}$ continue to decrease in many regions of the world, due to the introduction of more stringent legislation and the application of $\mathrm{SO}_{2}$ and $\mathrm{NO}_{\mathrm{x}}$ reduction technologies to stationary sources and the introduction of catalytic converters in motor vehicles, the contribution of shipping to the atmospheric emissions of these gases will increase. Shipping is increasingly being recognised as a source of air pollution, and legislation is being planned to control emissions from marine sources. Seawater based FGD methods could be conveniently applied to these sources.

\section{REFERENCES}

[1] Foell, W., Green, C., Amann, M., Bhattacharya, S., Carmichael, G., Chadwick, M., Cinderby, S., Haughland, T., Hettelingh, J.-P., Hordijk, L., Kuylenstierna, J., Shah, J., Shrestha, R., Streets, D. and Zhao, D. Energy use, emissions, and air pollution reduction strategies in Asia. Water, Air and Soil Pollution 85, 2277 2282, (1995).

[2] Radojevic, M. Sea changes. Chemistry in Britain 32 (11) 47-49, (1996).

[3] Radojevic, M. The use of seawater for flue gas desulphurisation. Environmental Technology Letters 10, 71-76, (1989).

[4] Radojevic, M. Disposal of Flue Gases. International Patent Application B01D 53/14, World International Property Organisation, Publication no. WO 91/12875, (1991).

[5] Rees, R.L. The removal of sulphur from flue gases. Journal of the Institute of Fuel 25, 350-357, (1953).

[6] Kelly, F.H.C. Design and operation of a counter current gas scrubbing system. Proceedings Australian I.M.M.(Inc.), N.S., Nos. 152-153, 17-39, (1949).

[7] O.E.C.D. Major Air Pollution Problems: The Japanese Experience. Report of the Air Management Sector Group, Paris, (1974).

[8] Ikenaga, Y. Controlling the desulphurisation of stack gases with sea-water. Japan Kokai, 49/110570, 349-351, (1974).

[9] Izumi, K. Apparatus and method for desulphurisation of exhaust gas with seawater. Japan Kokai, 49/117393, 493-496, (1974).

[10] Namikawa, Y. Desulphurising waste gases by absorption with electrolysis product of sea water or brine. Japan Kokai, 49/26175, 383-386, (1974).

[11] Abrams, J.Z. and Haidinger, J. New seawater-based flue gas desulphurisation process. Proceedings of the American Power Conference, Chicago, April 1988, (1988).

[12] Abrams, J.Z., Zaczek, S.J., Benz, A.D. and Awerbuch, L. Use of seawater in flue gas desulfurisation. Journal of the Air Pollution Control Association, 38, 969-974, (1988).

[13] Radojevic, M. Flue gas desulphurisation using seawater. Fourth International Conference on Environmental Contamination, Barcelona, October 1990, CEP Consultants, Edinburgh, 129-131, (1990).

[14] Radojevic, M. Scrubbing of flue gases with sea-water. International Conference on Environmental Control of Combustion Processes. October 1991, Honolulu, paper no. 34, (1991). 
[15] Clarke, A.G. and Radojevic, M. Chloride ion effects on the aqueous oxidation of $\mathrm{SO}_{2}$. Atmospheric Environment 17, 617-624, (1993).

[16] Clarke, A.G. and Radojevic, M. Oxidation rates of $\mathrm{SO}_{2}$ in sea-water and sea-salt aerosols. Atmospheric Environment 18, 2761-2767, (1994).

[17] Radojevic, M. and Tressider, D.A. Laboratory and pilot plant studies of $\mathrm{SO}_{2}$ absorption in seawater. New Zealand Institute of Chemistry Conference, Auckland, December 1993, (1993).

[18] Radojevic, M. and Tressider, D.A. Absorption of flue gases by water. Nature 356, p. 391, (1992).

[19] Radojevic, M. Opportunity NO $\mathrm{NO}_{\mathrm{x}}$ Chemistry in Britain 34 (3), 30-33, (1998).

[20] De Baar, H.J.W. and Stoll, H.C. Storage of carbon dioxide in the oceans. In Climate and Energy: The Feasibility of Controlling $\mathrm{CO}_{2}$ Emissions. Okken, P.A., Swart, R.J. and Zwerver, S. (eds.) Kluwer Academic Publishers, Dordrecht, pp. 143- 177, (1989).

[21] Sarmiento, J.L. Ocean carbon cycle. Chemical and Engineering News (C\&EN), May 1993, 30-43, (1993).

[22] Herzog, H., Golomb, D. and Zemba, S. Feasibility, modeling and economics of sequestering power plant $\mathrm{CO}_{2}$ emissions in the deep ocean. Environmental Progress 10, 64- 74, (1991).

[23] Marchetti, C. On geoengineering and the $\mathrm{CO}_{2}$ problem. Climatic Change 1, 5968, (1977).

[24] Marchetti, C. Constructive solutions to the $\mathrm{CO}_{2}$ problem. In Man's Impact on Climate. Bach, W., Pankrath, J. and Kellog, W.(eds.). Elsevier Scientific Publishing Co., Amsterdam, pp. 299- 311, (1979).

[25] Baes, C.F. Jr., Beall, S.E., Lee, D.W. and Marland, G. The collection, disposal, and storage of carbon dioxide. In Interactions of Energy and Climate, Bach, W., Pankrath, J. and Williams, J. (eds.) D. Reidel Publishing Co., Dordrecht, pp. 495-519, (1980).

[26] Mitsubishi Heavy Ind. KK. Carbon dioxide disposal in sea water- by injecting to a specified depth. Japanese Patent Abstracts, 13 June 1990, class J, no. 90134564/18, JO 2080-316-A, (1990).

[27] Haugan, P.M. and Drange, H. Sequestration of $\mathrm{CO}_{2}$ in the deep ocean by shallow injection. Nature 357, 318-320, (1992).

[28] Steinberg, M. and Albanese, A.S. Environmental control technology for atmospheric carbon dioxide. In Interactions of Energy and Climate. Bach, W., Pankrath, J. and Williams, J. (eds.). D. Reidel Publishing Co., Dordrecht, pp. 521-551, (1980).

[29] Strömmen, S.O. and Hjelm, F. Sulphur in flue gases can safely be absorbed by seawater and returned to the oceans. Desulphurisation 3, Institution of Chemical Engineers Symposium Series No. 131, pp. 95- 108, (1993).

[30] Maclntyre, F. Why the sea is salt. Scientific American 203, 104-115, (1970).

[31] Weart, S.R. The discovery of global warming. Physics Today, January 1997, 3440, (1997).

[32] Spedding D.J. Sulphur dioxide absorption by sea water. Atmospheric Environment 6, 583-586, (1972).

[33] Bromley, L.A. Use of sea-water to scrub sulphur dioxide from stack gases. International Journal of Sulphur Chemistry, Part B 7, 77-84, (1972).

[34] Mustacchi, C., Armenante, P. and Cena, V. Carbon dioxide removal from power plant exhausts. Environment International 2, 453-456, (1979). 
[35] Steinberg, M. and Cheng, H.C. A systems study for the removal, recovery and disposal of carbon dioxide from fossil fuel power plants in the U.S. 78th Annual Meeting of the Air Pollution Control Association, Detroit, June 1985. Paper 8526.5, (1985).

[36] Mitsubishi Jukogyo Kabushiki Kaisha Method for the fixation of carbon dioxide, apparatus for fixing and disposing carbon dioxide, and apparatus for the treatment of carbon dioxide. European Patent Application no. 90250288.9, (1991).

[37] Oikawa, K., Yongsiri, C., Takeda, K. and Harimoto, T. Seawater flue Gas desulphurization: its technical implications and performance results. Environmental Progress 22, 67- 73, (2003). 
Table 1. Values of equilibrium constants for $\mathrm{SO}_{2}$ and $\mathrm{CO}_{2}$ at $25^{\circ} \mathrm{C}$.

\begin{tabular}{lll}
\hline Constant & $\mathrm{SO}_{2}$ & $\mathrm{CO}_{2}$ \\
\hline $\mathrm{H}\left(\mathrm{mol} \mathrm{L}^{-1} \mathrm{~atm}^{-1}\right)$ & 1.242 & 0.031 \\
$\mathrm{~K}_{1}\left(\mathrm{~mol} \mathrm{~L}^{-1}\right)$ & 0.0132 & $4.3 \times 10^{-7}$ \\
$\mathrm{~K}_{2}\left(\mathrm{~mol} \mathrm{~L}^{-1}\right)$ & $6.24 \times 10^{-8}$ & $5.61 \times 10^{-11}$ \\
$\mathrm{H}^{*}\left(\mathrm{~mol} \mathrm{~L}^{-1} \mathrm{~atm}^{-1}\right)$ & $1.19 \times 10^{7}$ & 1.371 \\
\hline
\end{tabular}

$\mathrm{H}^{*}$ is for $\mathrm{pH} 8$. 
Table 2. Experimental studies of $\mathrm{SO}_{2}$-seawater interactions

\begin{tabular}{|c|c|c|c|}
\hline Study/reference & Type of study & $\begin{array}{l}\mathrm{SO}_{2} \text { concentration } \\
(\mathrm{ppmv})\end{array}$ & Comments \\
\hline Spedding [32] & $\begin{array}{l}\text { Air containing } \\
\mathrm{SO}_{2} \text { passed } \\
\text { over seawater }\end{array}$ & $0.003-1.3$ & $\begin{array}{l}\text { Low concentrations not } \\
\text { relevant to flue gases }\end{array}$ \\
\hline Bromley [33] & $\begin{array}{c}\mathrm{SO}_{2} \text { in air } \\
\text { absorbed in } 6- \\
\text { inch by } 10 \text {-foot } \\
\text { spray and } \\
\text { packed tower }\end{array}$ & 890 & $\begin{array}{l}\text { Absorption efficiency } \\
\text { increased with increasing } \\
\text { liquid/ gas ratio. Between } \\
88.5 \text { and }>99.9 \% \text { of the } \\
\mathrm{SO}_{2} \text { could be absorbed }\end{array}$ \\
\hline $\begin{array}{c}\text { Clarke \& } \\
\text { Radojevic [16] }\end{array}$ & $\begin{array}{l}\text { Oxidation of } \\
\text { sulphite in } \\
\text { seawater }\end{array}$ & $\begin{array}{c}\text { Dissolved } \mathrm{S}(\mathrm{IV}) \\
\text { concentrations } \\
\text { between } 10^{-5} \text { and } \\
10^{-4} \mathrm{~mol} \mathrm{~L}^{-1}\end{array}$ & $\begin{array}{l}\text { Low concentrations not } \\
\text { relevant to flue gases. } \\
\text { Evaluated kinetic } \\
\text { constants. }\end{array}$ \\
\hline $\begin{array}{c}\text { Radojevic \& } \\
\text { Tressider [17] }\end{array}$ & $\begin{array}{l}\text { Air containing } \\
\mathrm{SO}_{2} \text { bubbled } \\
\text { through } \\
\text { seawater }\end{array}$ & 4000 ppmv & $\begin{array}{l}\text { Complete absorption of } \\
\mathrm{SO}_{2} \text {. Also studied buffer } \\
\text { capacity of seawater. }\end{array}$ \\
\hline
\end{tabular}


Table 3. Proposed methods of $\mathrm{CO}_{2}$ disposal in the ocean

\begin{tabular}{|c|c|c|c|c|c|}
\hline Reference & Method & Injection depth & $\begin{array}{l}\mathrm{CO}_{2} \\
\text { recovery }\end{array}$ & Scrubbing solution & Comments \\
\hline Marchetti $[23,24]$ & $\mathrm{SSCl}^{\mathrm{a}}$ & $N R^{d}$ & $50 \%$ & $\mathrm{~K}_{2} \mathrm{CO}_{3}$ & Injection into sinking thermohaline currents \\
\hline Mustacchi et al [34] & DIFG $^{b}$ & $240 \mathrm{~m}$ & $95 \%$ & - & Cost: $43 \%$ of total power produced \\
\hline Mustacchi et al [34] & SSCI & $160 \mathrm{~m}$ & $95 \%$ & Various absorbents & Cost: $20 \%$ of total power produced \\
\hline Mustacchi et al [34] & $\mathrm{SI}^{\mathrm{C}}$ & $10 \mathrm{~m}$ & NR & Seawater & Cost: $20 \%$ of total power produced \\
\hline Baes et al [25] & $\mathrm{SSCl}$ & $1000 \mathrm{~m}$ & $90 \%$ & $\begin{array}{l}\text { Various absorbents/ } \\
\text { Seawater }\end{array}$ & $\begin{array}{l}\text { Absorption of purified } \mathrm{CO}_{2} \text { into seawater followed } \\
\text { by deep sea injection of concentrated seawater } \\
\text { solution. }\end{array}$ \\
\hline Baes et al [25] & $\mathrm{SSCl}$ & $3000 \mathrm{~m}$ & $90 \%$ & Various absorbents & Injection of liquid $\mathrm{CO}_{2}$ \\
\hline Baes et al [25] & $\mathrm{SSCl}$ & $500 \mathrm{~m}$ & $90 \%$ & Various absorbents & Dropping of blocks of $\mathrm{CO}_{2}$ hydrate and dry ice. \\
\hline Steinberg \& Albanese [28] & $\mathrm{SI}$ & NR & $60 \%, 90 \%$ & Seawater & $\begin{array}{l}\text { Not feasible: more power is required than is } \\
\text { generated by power plant. }\end{array}$ \\
\hline Steinberg \& Albanese [28] & $\mathrm{SSCl}$ & $\begin{array}{c}500 \mathrm{~m} \text { for } \mathrm{CO}_{2} \text { gas } \\
2000 \mathrm{~m} \text { for liquid } \\
\mathrm{CO}_{2}\end{array}$ & $\begin{array}{l}90 \% \\
90 \%\end{array}$ & Monoethanolamine & $\begin{array}{l}\text { Cost: } 86 \% \text { of total power. Also proposed disposal } \\
\text { of solid } \mathrm{CO}_{2} .\end{array}$ \\
\hline Steinberg \& Cheng [35] & $\mathrm{SSCl}$ & $500 \mathrm{~m}$ and $3000 \mathrm{~m}$ & $90 \%$ & $\begin{array}{l}\text { Dow FS-1 } \\
\text { alkanolamine }\end{array}$ & $\begin{array}{c}\text { Cost: } 17 \% \text { of total power for } 500 \mathrm{~m} \\
18.2 \% \text { for } 3000 \mathrm{~m}\end{array}$ \\
\hline Herzog et al [22] & $\mathrm{SSCl}$ & $>700 \mathrm{~m}$ & $80-100 \%$ & Amine solutions & $\begin{array}{c}\text { Also considered membrane separation, cryogenIc } \\
\text { fractionation and air separation/ flue gas } \\
\text { recycling. Costs: between } 25 \text { and } 66 \% \text { of total } \\
\text { power. }\end{array}$ \\
\hline Mitsubishi [26] & $\mathrm{SSCl}$ & $200 m-500 m$ & NR & NR & $\begin{array}{c}\text { Mixing of } \mathrm{CO}_{2} \text { with water in a pressurised pipeline } \\
\text { to give } \mathrm{CO}_{2} \text { hydrate }\end{array}$ \\
\hline Mitsubishi [26] & SSCI & $>700 m \&<700 m$ & NR & NR & Injection of compressed $\mathrm{CO}_{2}$ \\
\hline Haugan \& Drange [27] & SSCl & $200-400 \mathrm{~m}$ & NR & NR & Direct injection of pure $\mathrm{CO}_{2}$ gas \\
\hline
\end{tabular}

${ }^{a} \mathrm{SSCl}=$ Scrubbing-Separation-Compression-Injection. ${ }^{b} \mathrm{DIFG}=$ Direct injection of flue gases. ${ }^{\mathrm{c}} \mathrm{SI}=$ Scrubbing-injection. ${ }^{\mathrm{d}} \mathrm{NR}=\mathrm{Not}$ reported. 
Table 4. Major ions in seawater

$\begin{array}{ll}\text { Ion } & \text { Concentration }\left(\mathrm{g} \mathrm{kg}^{-1}\right) \\ \mathrm{Cl}^{-} & 18.97 \\ \mathrm{SO}_{4}{ }^{2-} & 2.65 \\ \mathrm{HCO}_{3}{ }^{-} & 0.14 \\ \mathrm{Br}^{-} & 0.065 \\ \mathrm{Na}^{+} & 10.47 \\ \mathrm{Mg}^{2+} & 1.28 \\ \mathrm{Ca}^{2+} & 0.41 \\ \mathrm{~K}^{+} & 0.38\end{array}$

Table 5. Comparison between wet limestone FGD and seawater FGD (adapted from [37]).

\begin{tabular}{lll}
\hline Description & Wet limestone FGD & Seawater FGD \\
\hline $\mathrm{SO}_{2}$ removal efficiency & $80-95 \%$ & $90-98 \%$ \\
By-product & Gypsum & None \\
Required supporting systems & Wet limestone preparation & Aeration \\
& Oxidation and dewatering & Neutralisation \\
Capital cost & $100 \%$ & $75-80 \%$ \\
Operating cost & Medium & Low \\
\hline
\end{tabular}




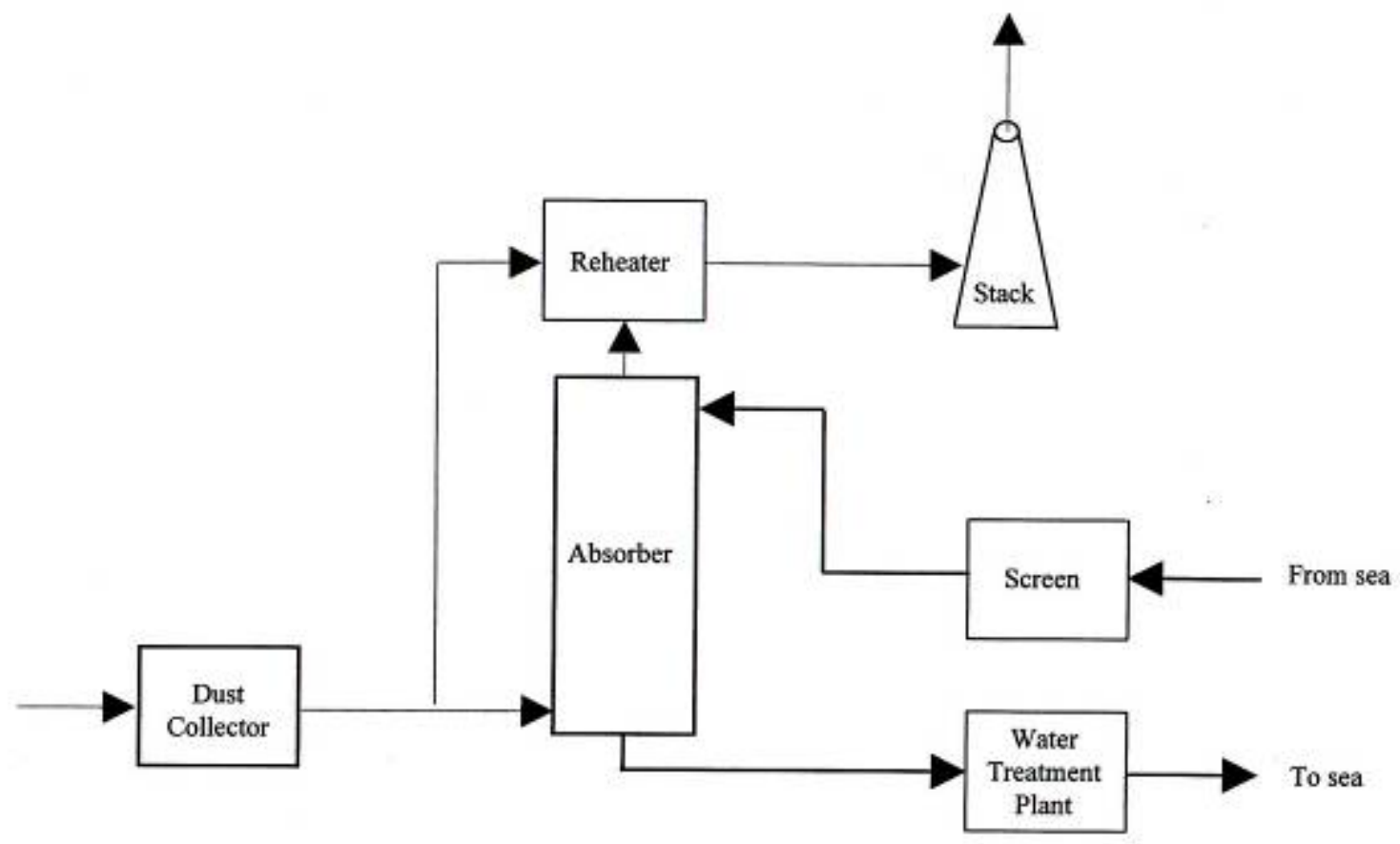

Fig. 1. Flow diagram of a typical seawater based desulphurisation plant. 


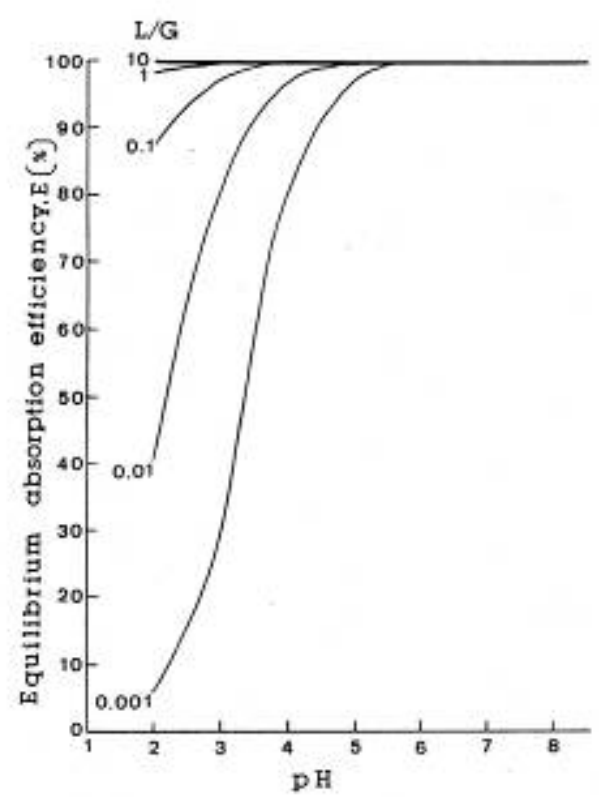

|a]

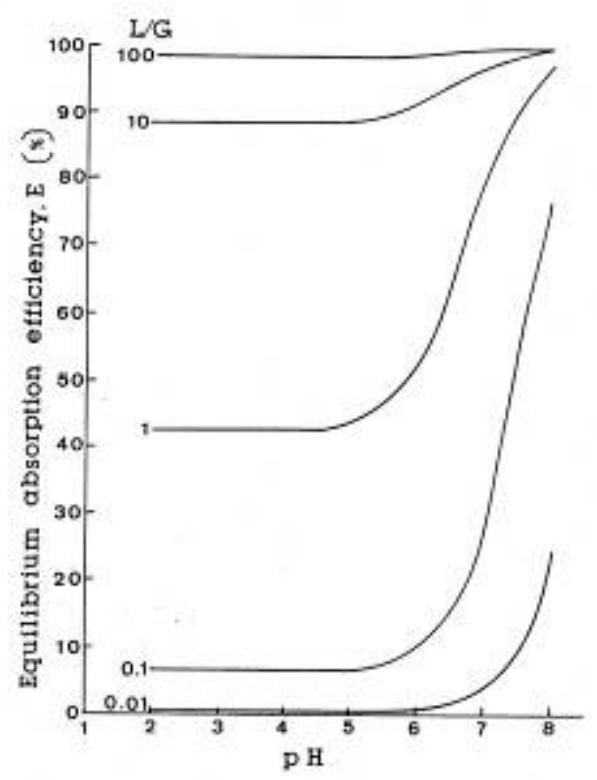

[b]

Fig. 2. Equilibrium absorption of (a) $\mathrm{SO}_{2}$ and (b) $\mathrm{CO}_{2}$ as a function of $\mathrm{pH}$ and volumetric liquid/gas $(L / G)$ ratio at $25^{\circ} \mathrm{C}$. 


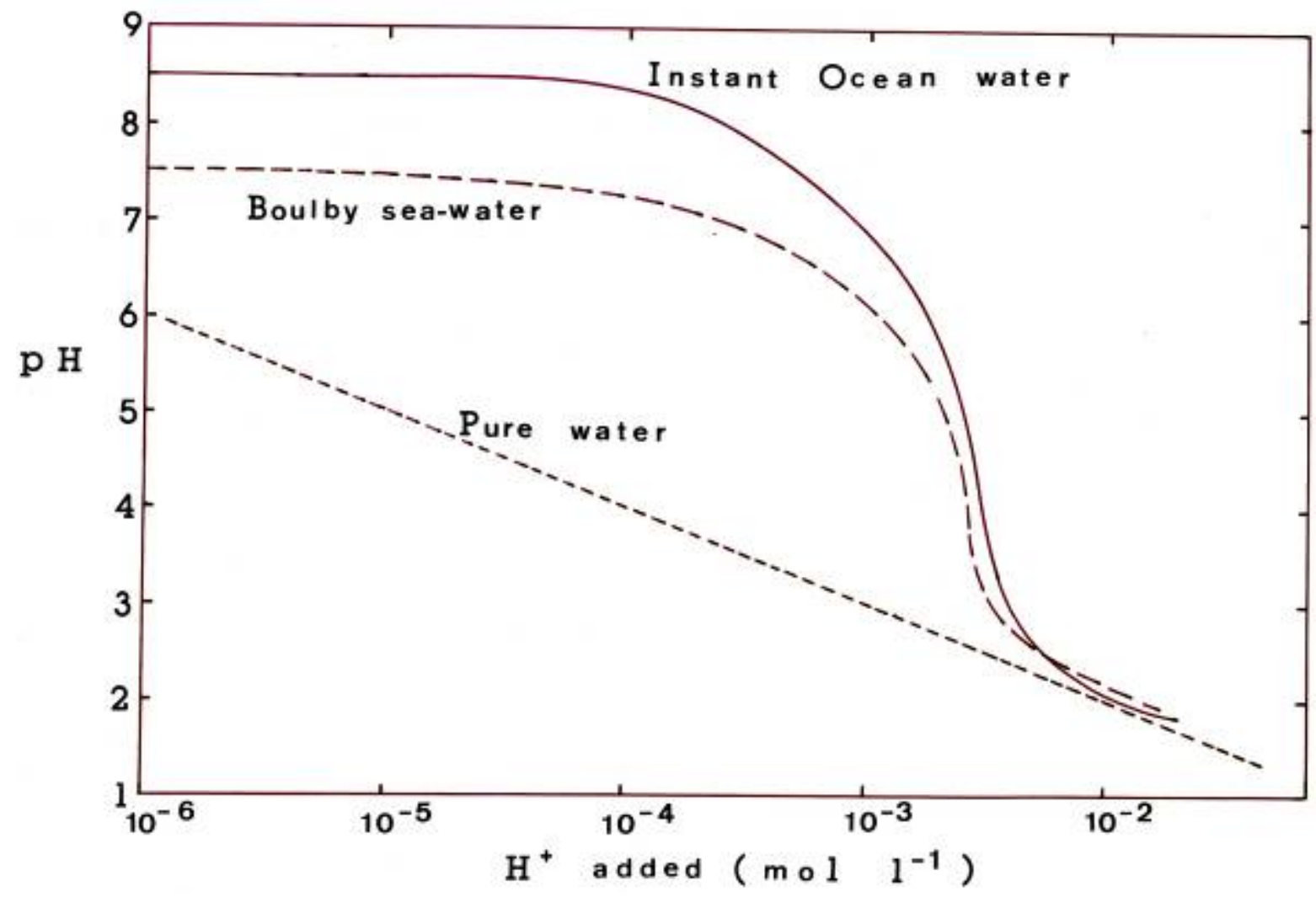

Fig. 3. The buffering capacity of seawater in artificial (Instant Ocean) and natural (Boulby) 


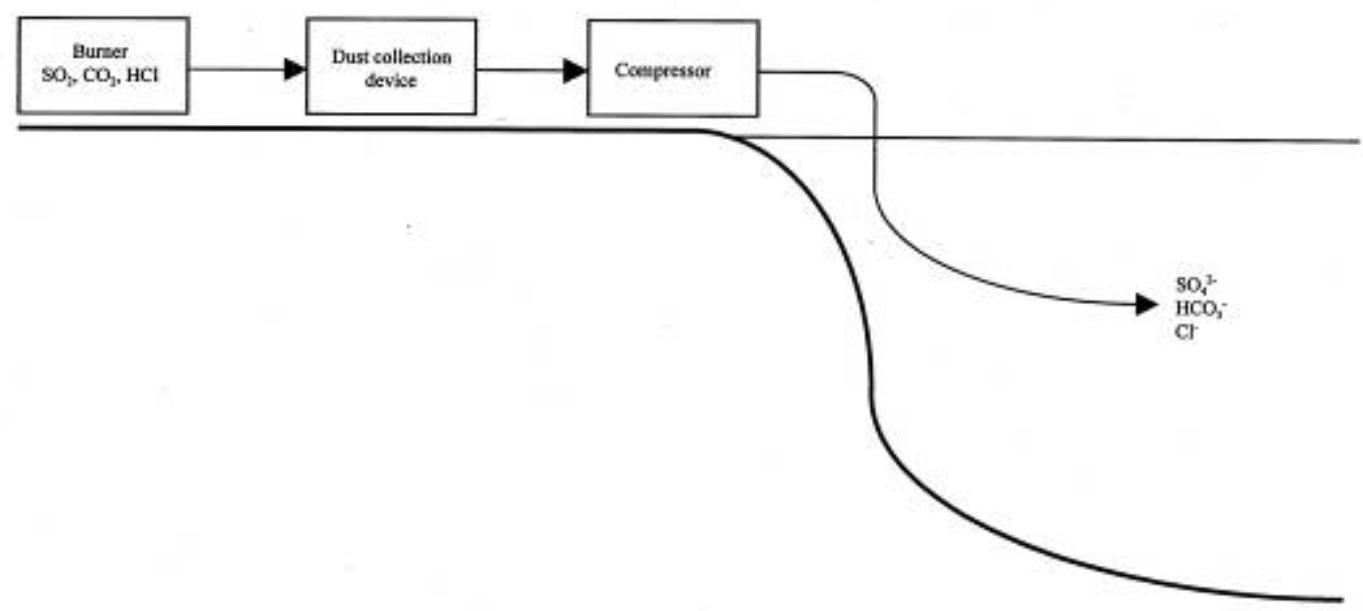

Fig. 4. Direct injection of flue gases into the sea samples 